\title{
Reproductive health of married adolescent women in squatter areas in Alexandria, Egypt
}

S.A. Sallam', A.A. Mahfouz' and N.I. Dabbous ${ }^{2}$

$$
\begin{aligned}
& \text { الصحة الإنجابية للمراهقات المتزوجات في المناطت العشبر ائية بالإسكندرية، مصر }
\end{aligned}
$$

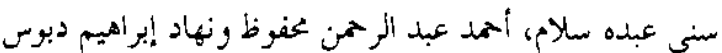

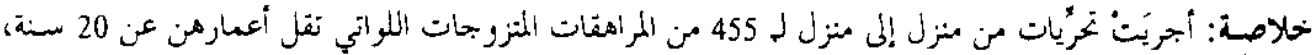

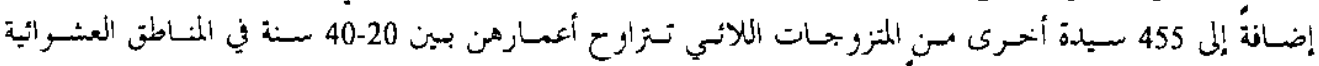

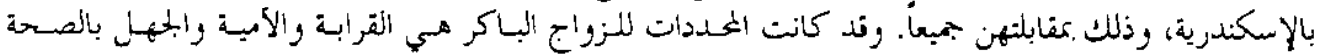

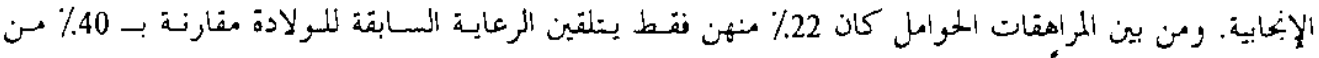

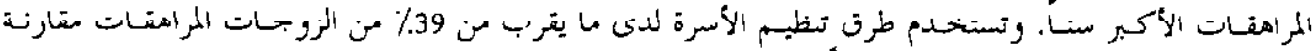

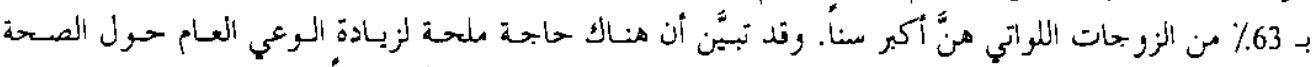

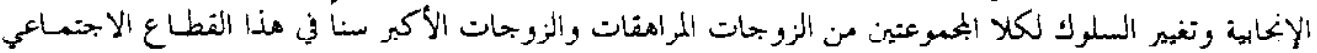

ABSTRACT through a house-to-house survey, 455 married adolescent women ( $<20$ years) and 455 married women aged 20-45 years from squatter areas in Alexandria were interviewed. Determinants of early marriage were consanguinity, illiteracy and unawareness of reproductive health. Of the currently prognant adolosoonts, $22 \%$ were receiving antenatal care compared with $40 \%$ of the older women. Farrily planning methods were currently being used by $39 \%$ of the adolescents and $63 \%$ of the older wives. Determinants of non-use were: adolescence, illiteracy and previous miscarriage/stillbirth. There is a need to increase public awareness of reproductive health and change the hehavinur of hoth groups of women in this under-privileged sector.

La santé génésique des adolescentes mariées dans des zones de squatters à Alexandrie (Egypte) RESUME Dans le cadre d'une enquête “ porte à porte ", on a interviewé 455 adolescentes mariées ( $<20$ ans) et 455 femmes mariées âgées de 20 à 45 ans dans des zones de squatters à Alexandrie. La consanguinité, l'analphabétisme et la méconnaissance de la santé génésique étaient les déterminants du mariage précoce. Parmi les adolescentes qui étaient alors enceintes, $22 \%$ bénéficiaient de soins prénatals contre $40 \%$ des femmes plus âgées. Des méthodes de planification familiale étaient alors utilisées par $39 \%$ des adolescentes et $63 \%$ des femmes plus âgées. Les déterminants de la non-utilisation étaient l'adolescence, l'analphabétisme et les fausses cuuchles/t Iurlinaissances précédentes. II faut accroître la sensibilisation du public à l'égard de la santé génésique et modifier le comportement de ces deux groupes de femmes dans ce secteur défavorisé.

'Department of Epidemiology; ${ }^{2}$ Department Family Health (Maternal and Child Health), High Institute of Public Health, University of Alexandria, Alexandria Egypt.

Received: 16/01/01; accepted: 03/04/01

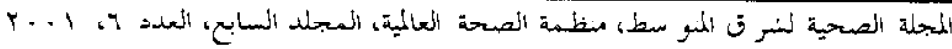




\section{Introduction}

In many parts of the developing world, girls marry shortly after puberty and sometimes even before. Teenage pregnancy is perceived in western countries as a problem with adverse social and medical consequences [1-3]. A similar picture is observed in some developing countrics [46]. On the other hand, a study in Saudi Arabia showed that pregnant teenagers are not a high-risk group if good prenatal care is provided [7]. Studies in developing countries $[8-10]$ have shown that the use of contraception among married adolescent women iss low compared to married adult women. Several sociocultural and economio conditions wore identificd as significant factors for early marriage for girls and low use of contraceptives [I]-14].

$\Lambda_{\mathrm{s}}$ in other parts of Egypt, unplanned population growth in Alexandria has led to the creation of numerous urban squatter areas. They are characterized by poor housing, sanitation and domestic and personal hygiene, and by unemployment and poverty $[15,16]$. In all, 81 there are squatter areas scattered over Alexandria, inhabited by more than one million inhabitants [17].

Data on reproductive health among married adolescent women in squatter areas of Alexandria are scarce or sometimes nonexistent. The objectives of the present work were to study reproductive health among married adolescent women in squatter areas in Alexandria and to identify factors that may affect early age of marriage among women.

\section{Methods}

This was a community-based cross-sectional study using a cluster-sampling technique; 30 clusters were selected. The health team performed a house-to-house survey, visiting houses consecutively to reach the target population of married adolescent women (a wife of less than 20 years old). Fifteen (15) married adolescent women were selected from each cluster. For each married adolescent woman a married adult ( $20-45$ years old) woman was selected from the same household or from adjacent neighbours and included in the study. Female interviewers contacted the wife and collected the data through personal interview.

Data were sorted, coded and analysed using the SPSS . Pearson $\chi^{2}$ and Student $I^{-}$ tests were used as tests of significance, taking 5\% as the level of significance. Mullivariate logistic regression analysio was performed to study the association between some potential risk factors for early age of marriage, unintended pregnancy and current non-use of family planning methods.

\section{Results}

\section{Characteristics of survey respondents}

The study included 455 adolescent married women and 455 adult married women. The mean age of the adolescent married women was 18.6 years and the mean age of the older women was 29.9 years. Forty-one (41) per cent of the adolescent women had lived in the same area before marriage, compared with $31 \%$ of the older women. The two samples reflect increases in education in women over time; only $37 \%$ of the adolescent women were illiterate, compared to $48 \%$ of the older women. In both groups, nearly all the women were housewives. Only a few were currently working as manual workers, trade workers or clerks. 


\section{Attitudes towards early marriage for girls}

The mean ideal age at marriage cited by all the women surveyed was about 20 years. Reasons given for selecting this age were: being sensible and mature enough for marriage, and being able to withstand the burden of pregnancy. Early marriage of girls (before the age of 20 years) vecurred more frequently in the families of the adolescent women surveyed than the older women (56.0\% and $48.4 \%$ respectively).

After adjusting all other variables for their effect on early marriage of girls in a multivariate logistic regression analysis (Table 1), the following variables were significantly related to early age of marriage for a girl (bofore the age of 20 years): coitsanguinity of the couple, wife's illiteracy, husband's illiteracy, a history of other girls in the wife's family marrying carly, and the

Table 1 Multivariate logistic regression model: adjusted odds ratios (OR) and $95 \%$ oonfidenoe intervals $(95 \% \mathrm{Cl})$ of potential risk factors determining early marriage for girls (under 20 years)

\begin{tabular}{|c|c|c|}
\hline Variable & OR & $95 \% \mathrm{Cl}$ \\
\hline Consanguineous marriage & 1.46 & $1.04-1.99$ \\
\hline Illiteracy of wife & 1.88 & $1.28-2.77$ \\
\hline Illiteracy of wife's mother & 1.23 & $0.86-1.77$ \\
\hline Living in an extended family & 1.26 & $0.75-2.11$ \\
\hline $\begin{array}{l}\text { Wife unaware of } \\
\text { reproductive health concept }\end{array}$ & 2.16 & $1.49-3.13$ \\
\hline $\begin{array}{l}\text { Early marriage of girls } \\
\text { in wife's family }\end{array}$ & 2.80 & $1.95-4.01$ \\
\hline Illiteracy of husband & 1.48 & $1.02-2.14$ \\
\hline $\begin{array}{l}\text { Husband unaware of } \\
\text { reproductive health concept }\end{array}$ & 1.12 & $0.76-1.65$ \\
\hline $\begin{array}{l}\text { Early marriage of girls } \\
\text { in husband's family }\end{array}$ & 1.22 & $0.84-1.77$ \\
\hline
\end{tabular}

wife being unaware of the concept of reproductive health.

\section{Fertility beliefs and behaviours}

As expected, older women had experienced more pregnancies than the adolescent women. The mean number of live births was 0.91 for the adolescents and 2.6 for the vlder women. A third (34.3\%) of the adolescent women were currently pregnant at the time of the interview compared to $10.7 \%$ or the vlder women.

The mean age at first pregnancy was 17.6 years for the adolescent wives and 19.3 ycars for the older wornen, which means that the average age at which both groups were pregnant for the first time was around adolesecmec. Most women in both groups had become pregnant within the first 6 months of marriage.

As regards current pregnanties, $27.0 \%$ of currently pregnant older women, compared with $4.2 \%$ of currently pregnant adoleseents, reported that their pregnalicy wis unintended. In a Multivariate logistic regression analysis identified certain determinants as significantly affecting currently unintended pregnancy (Table 2). They included having previously had four or more pregnancies, illiteracy of husband and being over 20 years.

\section{Reproductive morbidity and reproductive health care}

While more than $90 \%$ of all the women in the survey said antenatal care was important, only $22 \%$ of the currently pregnant adolescents and $40 \%$ of the currently pregnant older women had received any antenatal care. These percentages were similar for the women's previous pregnancies as well. The governmental maternal and child health $(\mathrm{MCH})$ unit was the most common source of care, followed by the governmental hospital.

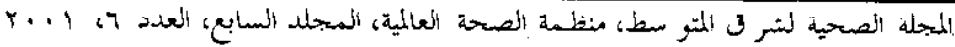


Table 2 Multivariate logistic regression model: adjusted odds ratios (OA) and $95 \%$ confidence intervals $(95 \% \mathrm{Cl})$ of potential risk factors determining unintended current pregnancy

\begin{tabular}{|c|c|c|}
\hline Variable & OR & $95 \% \mathrm{Cl}$ \\
\hline Wife over 20 years of age & 4.98 & $1.18-21.0$ \\
\hline Illiteracy of wife & 1.03 & $0.21-4.97$ \\
\hline Living in an extended family & 1.13 & $0.19-6.91$ \\
\hline $\begin{array}{l}\text { Wife unaware of reproductive } \\
\text { health concept }\end{array}$ & 1.29 & $0.34-6.51$ \\
\hline $\begin{array}{l}\text { Having four or more previous } \\
\text { pregnancies }\end{array}$ & 48.65 & $3.11-73.6$ \\
\hline Illiteracy of husband & 10.09 & $0.88-11.6$ \\
\hline $\begin{array}{l}\text { Husband unaware of } \\
\text { reproductive health concept }\end{array}$ & 3.03 & $0.84-10.9$ \\
\hline
\end{tabular}

Over three-quarters of the women in both groups $76.1 \%$ for adolescents and $75.4 \%$ for older women) stated that the hospital was the best place for delivery. However, about half of the women had delivered at home during their last pregnancy $(58.4 \%$ for adolescents and $61.3 \%$ for older women). Strong traditions, a preference for being near children and family members and a lack of monetary resources were given as reasons for delivering at home. Only $11.3 \%$ of adolescent and $12.9 \%$ of older women had been examined in the 40 days after delivery.

Almost a third of adolescent and older women reported having pain during intercourse $(38.8 \%$ and $34.2 \%$ respectively). The presence of blood was the trigger for women to seek medical advice. More than $70.0 \%$ of all the women reported having excessive vaginal discharge. In many cases this discharge was yellowish, smelled bad or caused itching. Less than $5 \%$ had sought medical treatment. Over half the adolescent and older women knew about sexually transmitted diseases $(51.6 \%$ and $61.5 \%$ respectively), including AIDS, syphilis and gonorrhoea. Suggested methods of protection against these diseases included chastity, conforming with religious beliefs and periodic examination.

\section{Family planning}

All the women surveyed knew about family planning methods, although older women knew about more medlods thall atolesent women did. When asked where they had learned about family planning, television ranked first for both groups $(90 \%)$. Furthermore, $95 \%$ of the women in both groups approved of the use of family planning, reconmending it because life is cxpensive, and women who have many children suffer from bad health. The few who were opposed to family planning did so because they considered: it went against religious beliefs, children were gifts from God and one should not prevent their birth, and many children gave good status to their families. Both groups of women felt that family planning was primarily a joint decision between the husband and wife.

Only $38.6 \%$ of the adolescent wives, compared to $63.1 \%$ of the older wives, were using contraception at the time of the survey. Of those using contraception, the adolescent wives were more likely than the older women to be using an intrauterine device (IUD) ( $81 \%$ versus $71 \%$ respectively). Older women were more likely (14\%) than adolescents $(6 \%)$ to be using the contraceptive pill. Multivariate regression analysis showed that the determinants of non-use of contraception included: being an adolescent wife, being illiterate, having an illiterate mother, having no radio or television in the house, and a previous pregnancy that resulted in a stillbirth or miscarriage (Table 3 ). 
Governmental organizations were the main providers of family planning services to the women in this study, with $59 \%$ of the adolescent wives and $37 \%$ of the older wives attending $\mathrm{MCH}$ units. As regards the services, $80 \%$ of the adolescent wives and $87 \%$ of the older wives said they were satisfied with family planning services, primarily because of the considered they received good care. Those reporting dissatisfaction did so because they felt no real care was provided. When asked how services could be improved, women suggested more working staff and longer working hours.

Table 3 Multivariate logistic regression model: adjusted odds ratios (OR) and $95 \%$ confidence intervals $(95 \% \mathrm{Cl})$ of potential risk factors determining curront non-ucc of family planning

\begin{tabular}{|c|c|c|}
\hline Variable & OR & $95 \% \mathrm{Cl}$ \\
\hline Wife under 20 years of age & 1.60 & $1.04-2.46$ \\
\hline Illiteracy of wife & 1.91 & $1.12-2.78$ \\
\hline Working woman & 4.84 & $0.98-23.8$ \\
\hline Illiteracy of wife's mother & 1.50 & $1.02-2.21$ \\
\hline Living in an extended family & 1.72 & $0.9:-3.02$ \\
\hline $\begin{array}{l}\text { Having no access to media } \\
\text { (radio, television) }\end{array}$ & 1.78 & $1.04-3.02$ \\
\hline $\begin{array}{l}\text { Wife unaware of reproductive } \\
\text { health concept }\end{array}$ & 1.03 & $0.67-1.59$ \\
\hline $\begin{array}{l}\text { Having four or more previous } \\
\text { pregnancies }\end{array}$ & 1.23 & $0.94-3.01$ \\
\hline $\begin{array}{l}\text { Failure of previous pregnancy } \\
\text { (miscarriage, stillbirth) }\end{array}$ & 5.75 & $2.46-13.4$ \\
\hline Illiteracy of husband & 1.32 & $0.89-1.96$ \\
\hline $\begin{array}{l}\text { Husband unaware of } \\
\text { reproductive health concept }\end{array}$ & 1.13 & $0.74-1.72$ \\
\hline
\end{tabular}

\section{Discussion}

A study using data from 40 demographic and heaith surveys showed that a substantial proportion of women in developing countries continue to marry as adolescents [18]. The study found that $20 \%-50 \%$ of women married or entered a union by 18 years, and $40 \%-70 \%$ by their 20 th birthday [18]. The Egyptian Demographic Health Survey in 1998 [19] showed that $10 \%$ of teenagers in Egypt had begun childbearing.

Our study showed that there were few differences between adolescent and older married women that could not be explained by or were not a consequence of the age difference. The younger women seemed to be slightly better educated, possibly because of greater educational opportunities available to them. As expected, the older wives had more children and were more likely to be using family planning methods than younger women. Egyptian women are unlikely to use family planning until they have had one or more children.

The issue of age of women at marriage showed some variation. The average age mentioned by most participants as the ideal age of marriage for gitls was around 20 years. All participants gave similar reasons for their preference, related to mental maturation, life experience and being able to deal properly with children. Yet the striking fact is that the average age of marriage of women in urban squatter areas was under 20 years. Certain factors were found to aftect early marriage for girls. These include illiteracy and family traditions; the latter also reflects illiteracy and lack of knowledge. Many studies in Egypt have found that education is the most important factor affecting female age at first marriage [20,21]. More public education is needed about the health benefits to both the mother

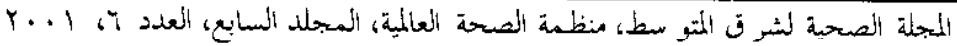


and the child when marriage and pregnancy are delayed until 20 years or older.

Reproductive health problems were observed among the adolescent women. Yet the response to these problems reflected total negligence and under-use of available health services. Most of the affected women did nothing or used traditional methods of treatment. Very few sought medical advice.

Most adolescent women agreed that antenatal care was good. Some participants emphasized the importance of antenatal care and its effects on the health of the mother and the child. Yet the uptake of antenatal care among the adolescents was not very high. Almost all participants believed that the suitable place of delivery was the hospital or $\mathrm{MCH}$ centres for reasons related to better care and hygiene. Thus women understand the benefits of delivering their babies in a hospital and the importance of antenatal care, yet not all women use these services. The reasons given in our study for delivering at home included having to stay with their children and lack of money. Additional research needs to be conducted to understand why women do not go to hospital to give birth and how access to antenatal care can he increased. The Egyptian Demographic Health Survey in 1998 [19] studied the utilization patterns of maternal health services in different parts of Egypt. It showed that there was poor use of these services with related reproductive morbidity. The results indicated that women do not seek medical care during pregnancy unless a problem arises.

I ack of use of maternal and related health services contributes to the relatively high maternal mortality and morbidity rates still prevalent in Fgypt, and to the high rates of unfavourable pregnancy outcomes. Such problems are greatly magnified in squatter areas where some of these services may not be available. It is recommended that new and innovative strategies be adopted to address the problem of underuse of maternal health services. Outreach programmes and media messages should target women, informing them of the importance of regular antenatal care and of the use of the available services for any morbid reproductive-related health problems.

The incidence of current pregnancy was very high among the group of adolescent women. About one-third was currently pregnant ( $34.3 \%$ ) compared to a national urban figure of $5.6 \%$ [19]. This paralleled the low rate of current use of family planning among the adolescent women $(38.6 \%)$ compared to the older women $(63.1 \%)$ and to the national urban figure of $56.4 \%$ [19]. Adolescent women need to he educated about the types of contraceptive methods available, and where and how to obtain them.

The unintended pregnancy rate among the adolescent women (4.2\%) was high compared to the national figure for married adolescents of $1.7 \%$ [19]. Yet this rate was low compared to the older women $(27.0 \%)$. The adolescent women are looking to prove their fertility through having more children, while the older group, especially those with several children. regard subsequent pregnancies as unintended. Because of the high percentage of unintended pregnancies among older women, and the potential for unintended pregnancies among younger women, family planning programmes should pay special attention to providing information on the effective use of contraceptive methods.

Our study demonstrated minor differences between married adolescent and adult women in terms of reproductive 
knowledge and behaviour. It provides information and insight into the needs of both groups, in an underprivileged sector of the population. There is clearly an urgent need to increase public awareness of reproductive health issues and change behaviour. Adolescents, as a vulnerable sector of the community, constitute a significant group with specific needs. Theit needs and aspirations as the adults of tomorrow merit consideration by the government, parents and society in general.

\section{Acknowledgements}

This work was funded by a grant from the Research Management Unit, Institutional Development Project, National Population Council of Egypt with a contract from the United States Agency for International Development/Cairo's FP/POPIII Project. Special thanks are due to Dr Laila Kafafi and Hala Aboutaleeb of Family Health International, Cairo Office for their technical assistance.

\section{References}

1. Rosenberg K, McEwan HP. Teenage pregnancy in Scotland: trends and risks. Scottish medical journal, 1991, 36:1724.

2. Ringdahl EN. The role of the family physician in preventing teenage pregnancy. American family physician, 1992, 45:2215-20.

3. Peckham S. Preventing unintended teenage pregnancies. Public health, 1993, 107:125-33.

4. Kurup A et al. Pregnancy outcome in unmarried teenage nulligravidae in Singapore. International journal of gynaecology and obstetrics, 1989, 30:305-11.

5. Sarkar CS, Giri AK, Sarkar B. Outcome of teenage pregnancy and labour: a retrospective study. Journal of the Indian Medical Association, 1991, 89:197-9.

6. Agyei WK, Mukiza-Gapere J, Epema EJ. Sexual behaviour, reproductive health and contraceptive use among adolescents and young adults in Mbale District, Uganda. Journal of tropical medicine and hygiene. 1994, 97:219-27.

7. Mahfouz AA et al. Teenage pregnancy: are teenagers a high risk group? Euro- pean journal of obstetrics, gynecology, and reproductive biology, 1995, 59:1720.

8. Mahmud M, Isiam MM. Adolescent contraceptive use and determinants in Bangladesh: evidence from Bangladesh Fertility Survey 1989. Contraception, 1995, 52:181-6.

9. Bahl L, Kaushal RK. Nutritional status, social awareness and attitudes towards marriage of adolescents in a tribal ICDS block of Himachal Pradesh. Indian pediatrics, 1994, 32:1094-7.

10. Assaad M, Bruce J. Empowering the next generation: girls of the Maqattam garbage settlement. Seeds, 1997, 19:24-8.

11. CI-Bakly AA. Determinants of adolescent fertility in Egypt. In: Studies in African and Asian demography: COC Annual Seminar. Cairo, Fgypt Cairo Demographic Centre, 1991:153-74.

12. Lane SD. Gender and health in rural Egyptian households. In: Sirageldin I, Davis $\mathrm{R}$, eds. Towards more efficacy in women's health and child survival strategies: combining knowledge for practical solutions. Report of the Johns Hopkins University-Ford Foundation Regional Workshop, Cairo, Egypt, 2-4 December,

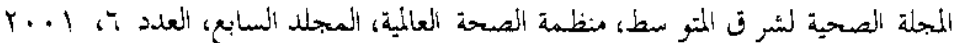


1990. Baltimore, Johns Hopkins University, School of Hygiene and Public Health, 1992:145-67.

13. Barnett B. Gender norms affect adolescents. Network, 1997, 17:10-13.

14. Westall J. Poor education linked with teen pregnancies. British medical journal, 1997, 314:537-9.

15. Mahfouz AA et al. Ecological determinants of intestinal parasitic infections among pre-school children in an urban squatter settlement of Egypt. Journal of tropical pediatrics, 1997, 43:341-4.

16. Assessment of health and environmental status of Mawa el Sayadeen squatter area in Alexandria. Alexandria, United Nations Children's Fund, 1996 (UnpubIIsned Final Project Report).

17. Squatter areas in Alexandria by population and square area. Alexandria, Health
Information Centre, Alexandria Directorate of Health Affairs, 1996.

18. Singh S, Samara R. Early marriage among women in developing countries. International family planning perspectives, 1996, 22:231-7.

19. Egypt Demographic and Health Survey. Cairo, National Population Council, 1995.

20. El-Tigi J. Egyptian marriage patterns. In: Moreland S, ed. Understanding demographic behaviour in Egypt: studies from the Demographic and Health Survey 1995. Cairo, National Population Council, 1990.

21. Ibrahim B et al. Transition to adulthood: a national survey of Egyptian adolescents. New York, The Poputation Councll, 2000.

In view of the need to strengthen national capacity in evidence-based strategic planning for reproductive health, research is regarded as a priority area for both programme development and programme implementation. In support of establishing a database on reproductive heath research for enabling exchange of research-related experience between and within countries of the Region, the Regional Office formulated a project for developing a directory for reproductive health research.

Source: The Work of WHO in the Eastern Mediterranean Region. Report of the Regional Director 1 January-31 December 2001 